\title{
Agronomic performance of blackberry cultivars in environmental protection area
}

\author{
Lorena da Silva Soler*ं, Luiz Antonio Biasi ${ }^{[0}$ \\ Federal University of Paraná, Curitiba, Brazil \\ *Corresponding author, e-mail: loosoler@gmail.com
}

\begin{abstract}
The demand for blackberry has been increasing due to the results of studies on its nutraceutical properties. Moreover, the rusticity of its plants allows its cultivation with reduced use of pesticides, becoming feasible to grow it in areas of environmental protection (APA). As a non-traditional crop in the country and its requirement in specific climatic conditions, there is a lack of studies about management techniques and the adaptability of cultivars in different regions. Thus, it is necessary to study phenological behavior and fruit quality in potential regions. Therefore, this work aimed to verify the adaptability of blackberry cultivars in environmental protection area in Pinhais - PR (Brazil), with no use of pesticides, as well as to evaluate the quality of the fruits produced under this condition, focusing on the recommendation of the cultivars more adapted and the best destination of fruits produced. For this, the phenological and productive performance of seven blackberry cultivars: Tupy, Guarani, Cherokee, Xavante, Brazos, Choctaw, and Arapaho were observed during the cycles of 2017/2018 and 2018/2019. Brazos cultivar had the earliest harvest period, Guarani and Xavante cultivars were intermediate and Tupy and Cherokee cultivars were later in the region. The highest yields were obtained with the cultivars Tupy, Guarani, Xavante, Cherokee, and Brazos. The harvest period extended from November to January. Tupy cultivar produces larger fruits and is the most recommended for marketing as fresh fruit. Other cultivars are recommended for industrialization.
\end{abstract}

Keywords: blackberry, small fruits, Rubus spp.

\section{Introduction}

The interest in small fruits has been growing in Brazil, mainly after the discovery of its nutraceutical properties. Among these fruits, there is the blackberry, which has high levels of antioxidants, especially flavonoids and anthocyanins. These substances reduce the effect of free radicals in the organism and also have antiinflammatory, antiallergic, antithrombotic, antimicrobial and antineoplastic activity (Hirsch et al., 2012; Croge et al., 2016).

The crop also draws the attention of producers, due to its high added value and inherent rusticity of the plants. Production can be carried out even without the use of pesticides and in organic production, fulfilling another growing demand from the population, for agricultural products from sustainable and organic production systems (Vieites, 2010; Antunes et al., 2014). Blackberry is a fruit tree with advantages as low cost of implantation and maintenance and rapid economic return, allowing to harvest fruits in the second year after implementation. These facts make their cultivation feasible on small farms and as a way of diversifying family farming, which can reverse stagnant local economies and multiply income (Antunes et al., 2014; Fachinello et al., 2011).

The current Brazilian production is not supplying the growing national demand. This fact, added to its short post-harvest life generates a fruit that reaches market shelves with high prices. With promising potential and good prospects for commercialization, the fruit can be consumed fresh or used to produce a wide variety of products that can be offered on rural tourism routes and in free markets (Antunes \& Hoffmann, 2012; Antunes \& Raseira, 2004; Cavender et al., 2019).

Due to its characteristics, it is possible to grow blackberries in Environmental Protection Areas (EPA). 
APAs are conservation units of the sustainable category that allow human occupation, including for agricultural purposes, however, with restrictions. The main restriction concerns the ban on the use of pesticides. Another requirement is to carry out sustainable conservation of the soil (BRASIL, 2011).

As a temperate fruit, the blackberry plant is highly dependent on climatic conditions for adaptation. Considering the great availability of cultivars, adaptability tests must be carried out to find the most productive cultivars in each region and to scale production in order to reduce risks of loss and increase the supply period of the fruit (Antunes \& Raseira, 2004; Martins et al., 2019; Croge et al., 2019).

In this scenario, this work aimed to verify the adaptability of the blackberry cultivars Tupy, Guarani, Xavante, Cherokee, Arapaho, Choctaw and Brazos in the Environmental Protection Area of Iraí - Pinhais/PR (Brazil), as well as to evaluate the quality of the fruits produced under such conditions, indicating which cultivars are more adapted to the region and their best destination.

\section{Material and Methods}

The research was conducted at the orchard of Canguiri Experimental Station, Federal University of Paraná (UFPR), located in Pinhais, PR, Brazil (Latitude: $25^{\circ} 23^{\prime} 16,11^{\prime \prime}$ S; Longitude: $49^{\circ} 07^{\prime} 55,33^{\prime \prime}$ W). The site is located within Iraí Environmental Preservation Area (APA), where pesticides are not allowed.

The climate in the region is classified according to Köppen's climate classification system as temperate oceanic climate ( $\mathrm{Cfb})$, with average temperatures in the coldest month below $18^{\circ} \mathrm{C}$ (mesothermal), and cool summers with average temperatures in the warmest month below $22^{\circ} \mathrm{C}$ and without a defined dry season.

The seedlings of the cultivars Tupy, Guarani, Xavante, and Cherokee were planted in 2011 and the cultivars Brazos, Choctaw and Arapaho in 2014, both spacing $0.5 \times 3.0 \mathrm{~m}$. The conduction system was trellis with three double rows of open $\mathrm{V}$-wires. In both ages, plants are considered in maximum production. In the second year of orchard implantation, plants begin to produce, during the third to ninth year plants are in the peak of production. The economic life of cultures well-conducted varies from twelve to fifteen years (Safley et al., 2006; Attilio et al., 2009; Antunes et al., 2014).

Soil analysis performed before planting demonstrated the following nutrient content: $P=14.10$

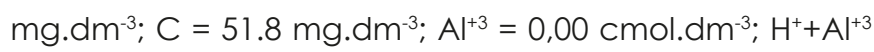
$=5.50 \mathrm{cmol} \cdot \mathrm{dm}^{-3} ; \mathrm{Ca}^{+2}=9.40 \mathrm{cmol} \cdot \mathrm{dm}^{-3} ; \mathrm{Mg}^{+2}=4.30 \mathrm{cmol}$. $\mathrm{dm}^{-3} ; \mathrm{K}^{+}=1.32 \mathrm{cmol} . \mathrm{dm}^{-3} ; \mathrm{SB}=14.79 \mathrm{cmol}^{\mathrm{d}} \mathrm{dm}^{-3} ; \mathrm{V}=73 \%$;
$\mathrm{pH}$ in $\mathrm{CaCl}_{2}=5 ; \mathrm{pH}$ in $\mathrm{SMP}=5.90$.

Evaluations were made in two productive cycles, $2017 / 2018$ and 2018/2019. Plant management and fertilization followed the same pattern for all cultivars and were performed according to soil analysis and technical recommendations for the cultivation of blackberry in the state of Paraná (Pauletti \& Motta, 2017).

During the winter, the application of sulfocalcic syrup was carried out, following the recommended ratio of 1:10 to $4^{\circ}$ Baumé, as well as winter pruning.

Weed control was carried out throughout the crop cycle by hand weeding.

After winter pruning, the plants were evaluated weekly. To evaluate the phenology, one stem of each useful plant per plot was marked. The scale used was based on the raspberry BBCH (Schmidt et al., 2001), considering the following stages: dormancy; beginning of budding; first visible flower buds; beginning of flowering ( $10 \%$ of open flowers); full bloom (50\% open flowers); end of flowering: most fallen petals; first ripe fruits; $10 \%$ of harvested fruits; $50 \%$ of harvested fruits (harvest peak); end of harvest.

The harvest occurred when the fruits reached the full maturation stage, that is when the film reached the shiny black color (Antunes \& Hoffmann, 2012). Harvesting was performed twice a week, and fresh mass (g) was determined using an analytical balance. The average yield per plant ( $\mathrm{kg}$ per plant) and estimated yield per hectare ( $\mathrm{h} \mathrm{ha}^{-1}$ ) were determined based on plant density per hectare $(6,667$ plants ha-1) and fresh fruit mass (g).

The meteorological data were obtained through SIMEPAR, whose meteorological station is located in Pinhais - PR (Brazil). Through daily average data were calculated the monthly minimum, average and maximum temperatures. Through hourly temperature data, the number of chilling hours was calculated (number of hours in which the average hourly temperature was $\leq 7.2^{\circ} \mathrm{C}$ ).

At the end of the harvest, the fruits were submitted to physical-chemical analysis, observing the following variables: equatorial and longitudinal diameter (mm); $\mathrm{pH}$; soluble solids content (SS) and titratable acidity (TA). The ratio between the diameters was calculated by dividing the longitudinal diameter by the equatorial one.

The $\mathrm{pH}$ was evaluated using a scale $\mathrm{pH}$ meter between 1 and 14, and the measuring electrode was inserted directly into the blackberry fruit juice (Instituto Adolfo Lutz, 2005).

TA was evaluated by neutralization titration according to the methodology described by ReyesCarmona (2005), in which a known volume of blackberry 
juice was titrated with $0.1 \mathrm{~N} \mathrm{NaOH}$ until the $\mathrm{pH}$ reached 8.2. The volume of $\mathrm{NaOH}$ used was required to calculate TA, which was expressed as a percentage of citric acid.

SS content was measured in ${ }^{\circ}$ Brix with a digital refractometer, and the direct reading was performed by adding a drop of the fruit juice on the apparatus prism (Instituto Adolfo Lutz, 2005).

The experimental design for agronomic performance was completely randomized in a twoway factorial arrangement $(7 \times 2), 7$ cultivars and two cycles, with three replications and three plants per plot were considered useful. The experimental design of the physicochemical analysis was completely randomized in a two-way factorial arrangement $(7 \times 2), 7$ cultivars and two cycles, with three replications and 10 fruits per plot.

The data were submitted to analysis of variance
(ANOVA) and when the treatments were considered significant, they were compared by Tukey's range test.

\section{Results and Discussion}

Climatic conditions varied widely between the two cycles evaluated. The first cycle (2017/2018) had an accumulation of chilling hours of 93 hours (Figure 1), while the second year had an accumulation of 130 hours. Considering that, even the least cold-demanding cultivars require at least 200 chilling hours, the values found in this study were low. Insufficient cold may cause poor and erratic bud break, and also prolongation of the plant cycle, including the occurrence of simultaneous phenological stages in the same plant (Croge et al., 2016).

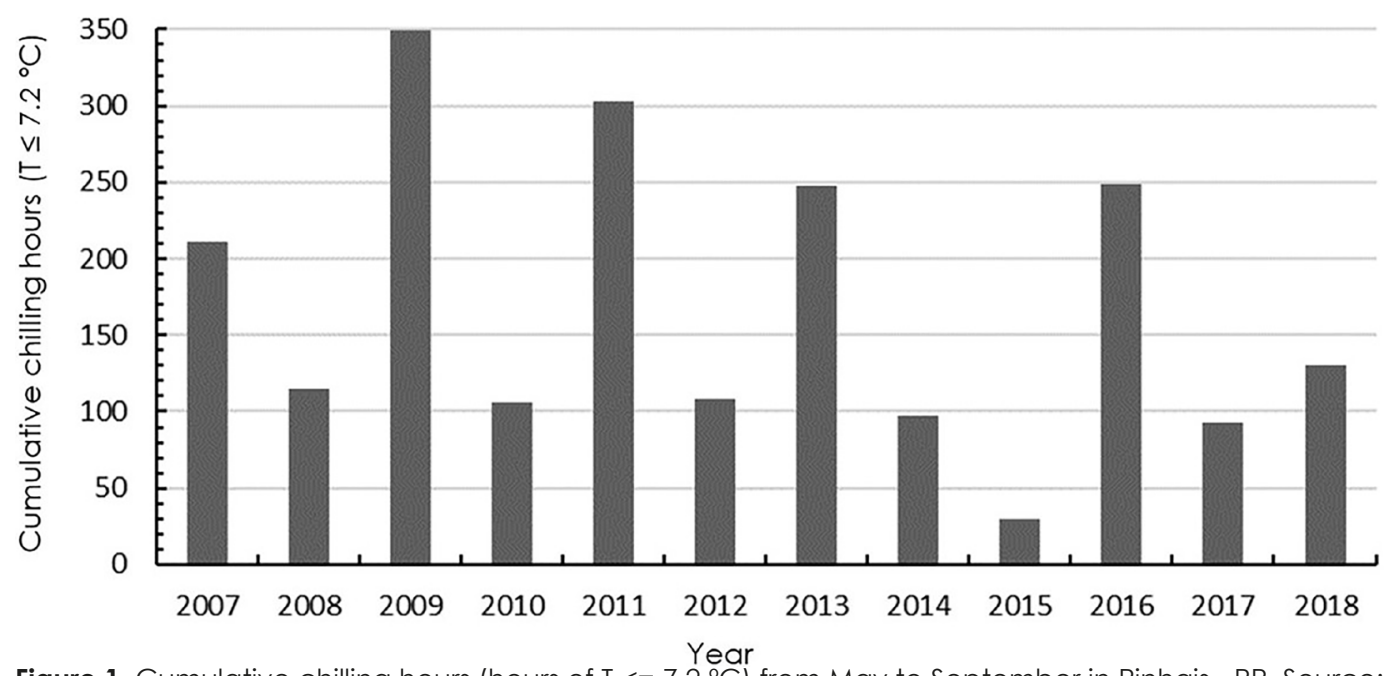

Figure 1. Cumulative chilling hours (hours of $\mathrm{T}<=7.2^{\circ} \mathrm{C}$ ) from May to September in Pinhais - PR. Source: SIMEPAR (2019)

During the years 2007 until 2018 in Pinhais PR (Brazil), the accumulation of chilling hours varied greatly (Figure 1). In the last 12 years, there was a sequential fluctuation of cold accumulation. The smallest accumulation was 30 chilling hours in 2015 and the largest was 349 chilling hours in 2009, with an average of 169.9 chilling hours during the whole period.

Accumulated rainfall data over the months in Pinhais - PR (Brazil) show that annual distribution of rainfall is quite irregular in the region. Accumulated monthly precipitation ranged from $4.4 \mathrm{~mm}$ to $243.2 \mathrm{~mm}$ during the first crop cycle and from $6.4 \mathrm{~mm}$ to $277.2 \mathrm{~mm}$ in the second cycle evaluated. As blackberry is a small plant with a shallow root system, water availability needs to be regular throughout the crop cycle (Antunes et al., 2012).

The lowest rates of accumulated precipitation were observed in April and July of 2018. In these months, however, the crop is still dormant, therefore, maintaining its respiratory activities decreased, resulting in a lower need for water availability.

From August, the water requirement increases, as the plants come out of dormancy and start to sprout. Also, from September, the blackberry is starting a new growth cycle, growing the stems responsible for the production of next year, hence, the lack of water can limit next year's production (Croge et al., 2019).

During the two cycles evaluated, dry periods were observed just before budding. In the first cycle it was observed that between 08/22/2017 and 09/23/2017, that is, for 33 days, no precipitation was recorded. In the second cycle, the greatest water scarcity was observed during the periods from 06/28/2018 to 07/30/2018, when the accumulated precipitation over 32 days totaled only $0.2 \mathrm{~mm}$.

This behavior was not observed in the 10 years before the survey, when, between 2007 and 2016, 
the rainfall behavior, despite following the pattern of decreasing rainfall in winter, did not present such intense water stress. Between these years, the less rainy months, which were August and May, presented averages of $84.52 \mathrm{~mm}$ and $88.24 \mathrm{~mm}$, respectively (SIMEPAR, 2019).

The lack of rain in the observed years may have affected plant phenology and productivity. Plant phenology varied between cycles and cultivars studied. It was possible to observe during the evaluations that some plants presented lack of definition in the phenological stage, with the occurrence of budding, flowering and fruiting in the same branch or branches of different plant heights.

By relating rainfall behavior to plant phenology (Figure 2) in both cycles (Figure 3), it is possible to observe that the pre-budding phases were preceded by water stress. Especially in the second cycle, where the lack of precipitation occurred before the beginning of crop budding, water stress may have delayed crop budding, since the study area was not equipped with an irrigation system.

Segantini et al. (2014) also noted, in the region of São Manuel - SP (Brazil), lack of rain during the winter months, especially in August, when there was no accumulated precipitation. The authors, testing different pruning times and the use of irrigation or not, noted that irrigation did not affect plant budding, however, increased yield and size of the fruits of Tupy cultivar produced.

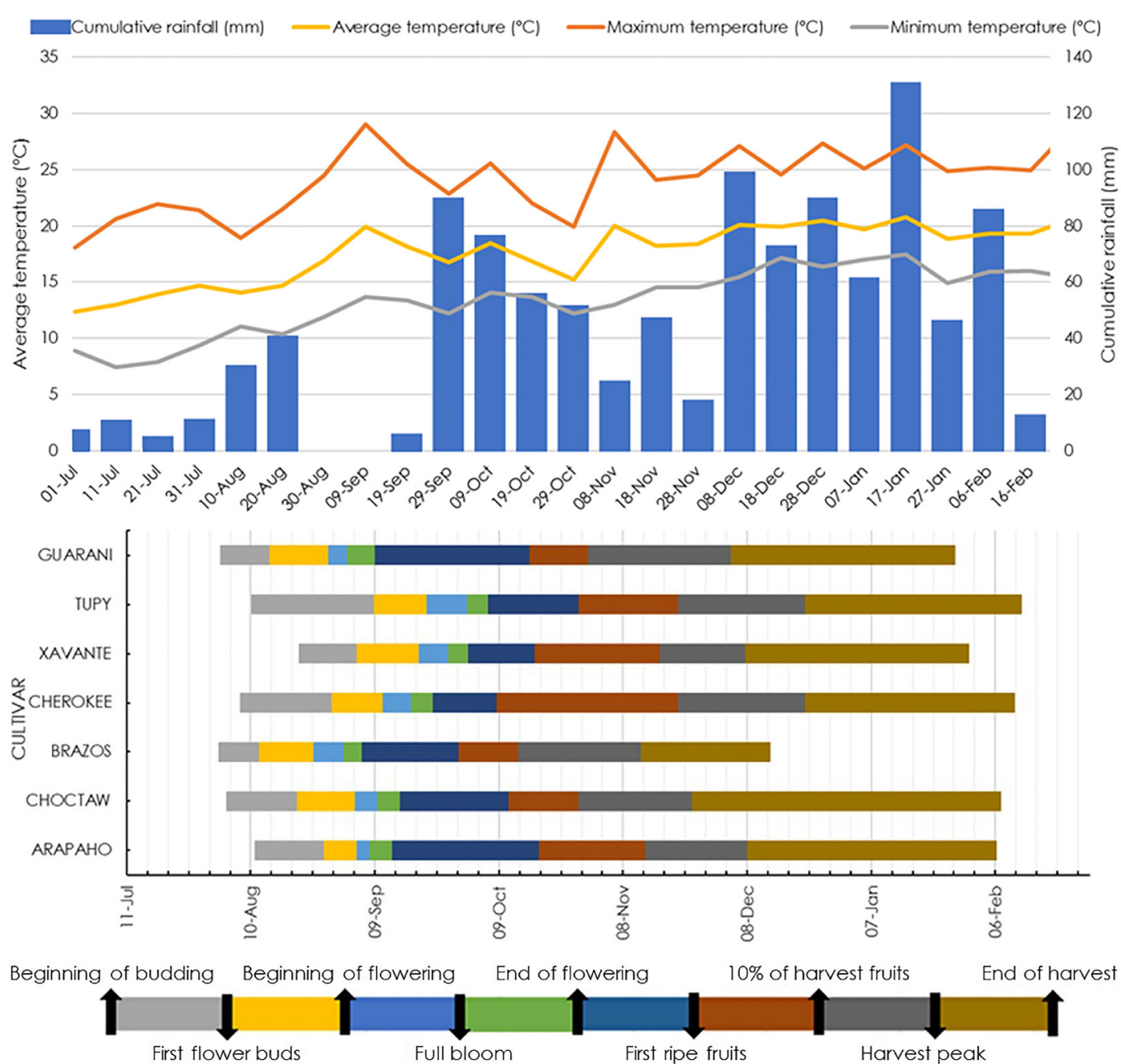

Figure 2. Average temperatures $\left({ }^{\circ} \mathrm{C}\right)$, cumulative rainfall $(\mathrm{mm})$ and phenological behavior of blackberry cultivars in the $2017 / 2018$ cycle in Pinhais - PR.

Croge et al. (2016) and Croge et al. (2019) also noted a lack of precipitation during winter months in Lapa - PR (Brazil) and Cerro Azul - PR (Brazil) regions, but the blackberry orchard in Lapa - PR (Brazil) region received irrigation and there was no loss in productivity. In contrast, the orchard of Cerro AzUl - PR (Brazil), without irrigation, presented low productivity, high incidence of diseases and occurrence of different phenological stages concomitantly in the same plant.

The rainiest months evaluated were December 2017 and October 2018, when water availability is important to achieve larger fruits, including to reach 
export standards. However, rain during harvesting can be harmful, negatively affecting fruit quality, as it favors the proliferation of fungal diseases and shortens postharvest life (Curi et al., 2015).

Average temperatures followed the pattern expected for the region, showing lower temperatures during June, July, and August, and higher from December to March. However, in both cycles, maximum temperatures above $20^{\circ} \mathrm{C}$ were present during winter. This thermal irregularity is not indicated for the crop in its hibernal period, as cold is essential to obtain a good budding rate. Dormancy can be encouraged by these temperature fluctuations, disordering budding, and flowering and impairing plant productivity (Antunes \& Hoffmann, 2012).

In the 2017/2018 cycle, the first cultivar to start budding was Brazos (Figure 2), so it was the earliest cultivar and the one that first reaches its chilling hours' requirement. According to Raseira \& Franzon (2012) 'Brazos' is the lower chilling demand cultivar $(<200 \mathrm{~h})$ among the studied cultivars. Antunes et al. (2010) also observed an early behavior of the cultivar Brazos, beginning its budding before other cultivars in Pelotas - RS (Brazil).
This cultivar also showed earliness production, compared to other cultivars, starting to present ripe fruits at the end of September. The same was observed by Tadeu et al. (2015) and Curi et al. (2015), for this cultivar, in the region of Lavras - MG (Brazil), where the plants also began to produce in the last week of September. At this time, the supply of this fruit in the country is still small and higher values can be obtained in marketing (Martins et al., 2019).

Nevertheless, under the conditions of this study, the duration of the harvest of this cultivar in the first evaluated cycle was short, extending for only 75 days (Table 1), unlike other cultivars, which during this same cycle had harvest durations of over 100 days. Tadeu et al. (2015) observed, in the region of Lavras - MG (Brazil), duration of harvest period for cultivar Brazos of 122 days.

The cultivar with later budding in the 2017/2018 cycle was Xavante, beginning its budding in the second half of August. All other cultivars presented a similar phenological pattern for this first cycle, budding in early August and harvesting until early February.

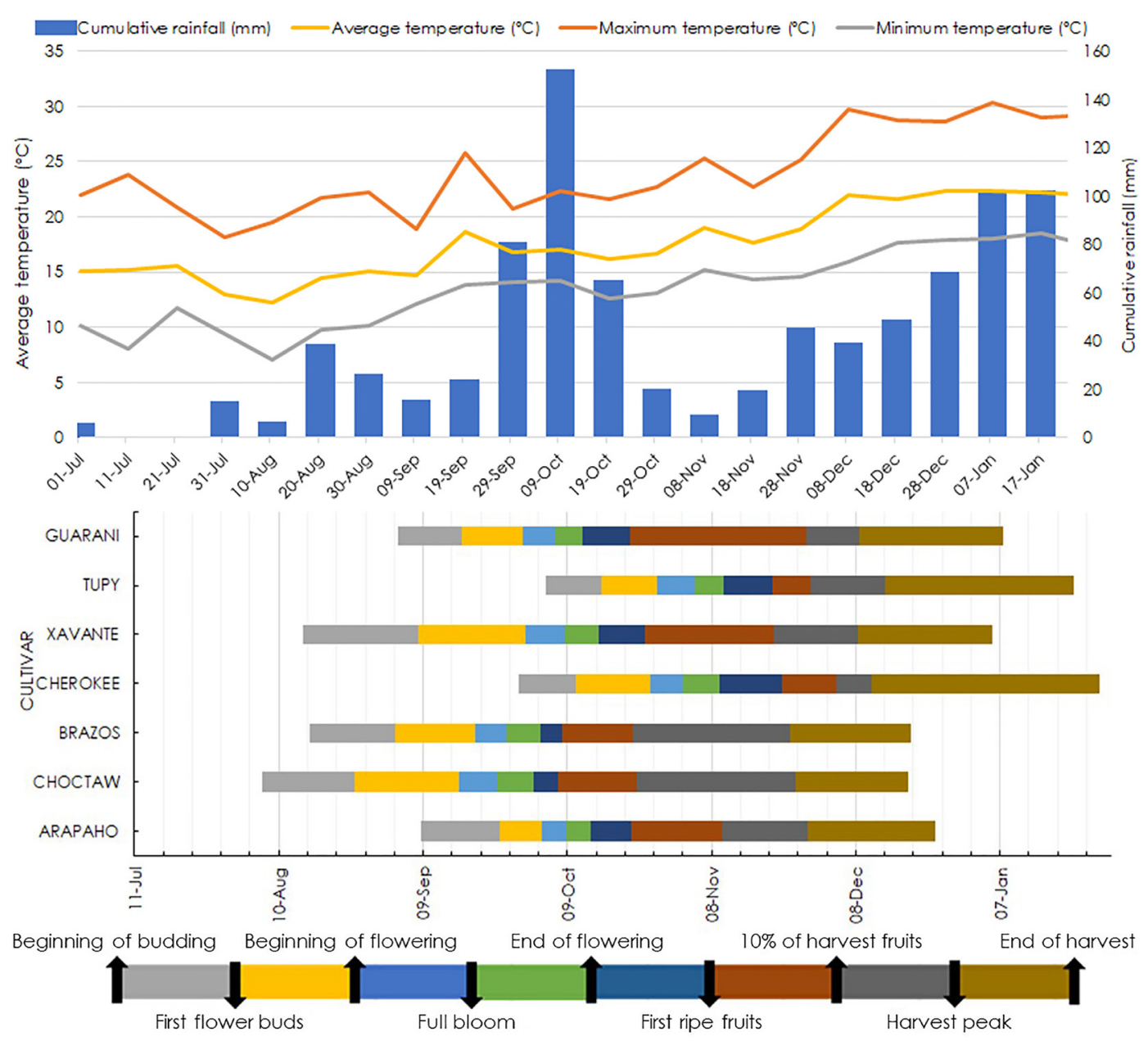

Figure 3. Average temperatures $\left({ }^{\circ} \mathrm{C}\right)$, cumulative rainfall $(\mathrm{mm})$ and phenological behavior of blackberry cultivars in the 2018/2019 cycle in Pinhais - PR. 
The cultivar with the highest harvesting period in the first cycle evaluated was Cherokee, lasting 125 days. The cultivar with the latest production was 'Tupy', ending the harvest on February 12th. All cultivars, except for 'Brazos', finished harvesting at the same time. According to Curi et al. (2015), a longer harvest duration decreases producer losses caused by rain and other harmful weather events, besides facilitating the production flow process when it is less concentrated, allowing production scheduling.

Table 1. Cumulative chilling hours (hours with temperature $\leq 7.2^{\circ} \mathrm{C}$ ) until the beginning of budding and harvest period length in 2017/2018 and 2018/2019 cycles. Pinhais - PR.

\begin{tabular}{ccccccccc}
\hline & $\begin{array}{c}\text { Cumulative chilling hours } \\
\text { until budding (h) }\end{array}$ & \multicolumn{2}{c}{$\begin{array}{c}\text { Harvest period length } \\
\text { (days) }\end{array}$} & \multicolumn{2}{c}{ Beginning of harvest } & \multicolumn{2}{c}{ End of harvest } \\
\hline Guarani & $17-18$ & $18-19$ & $17-18$ & $18-19$ & $17-18$ & $18-19$ & $17-18$ & $18-19$ \\
Tupy & 84 & 130 & 103 & 78 & $30 /$ out & $30 /$ out & $27 /$ jan & $27 /$ jan \\
Xavante & 88 & 130 & 107 & 63 & $21 /$ nov & $21 /$ nov & $12 / \mathrm{fev}$ & $22 /$ jan \\
Cherokee & 93 & 114 & 105 & 72 & $17 /$ nov & $21 /$ nov & $30 /$ jan & $05 /$ jan \\
Brazos & 88 & 130 & 125 & 66 & $08 /$ out & $04 /$ dez & $22 / \mathrm{dez}$ & $27 /$ jan \\
Choctaw & 84 & 114 & 75 & 72 & $29 / \mathrm{set}$ & $07 /$ out & $12 / \mathrm{nov}$ & $19 / \mathrm{dez}$ \\
Arapaho & 84 & 85 & 119 & 73 & $28 /$ out & $23 /$ out & $07 / \mathrm{fev}$ & $19 / \mathrm{dez}$ \\
& 88 & 130 & 111 & 63 & $13 / \mathrm{hov}$ & $22 /$ out & $06 / \mathrm{fev}$ & $24 / \mathrm{dez}$ \\
\hline
\end{tabular}

In the first cycle evaluated, it was possible to observe two harvest peaks (Figure 4). The first was in the second half of November, when the cultivar Xavante produced $380 \mathrm{~g}$ in one day. The second was at the end of December, in which the cultivar Tupy produced more than $400 \mathrm{~g} /$ day. This second peak took place approximately one week after a period of rainfall that reached $68 \mathrm{~mm}$ / day, it may have positively influenced the swelling of the fruit.

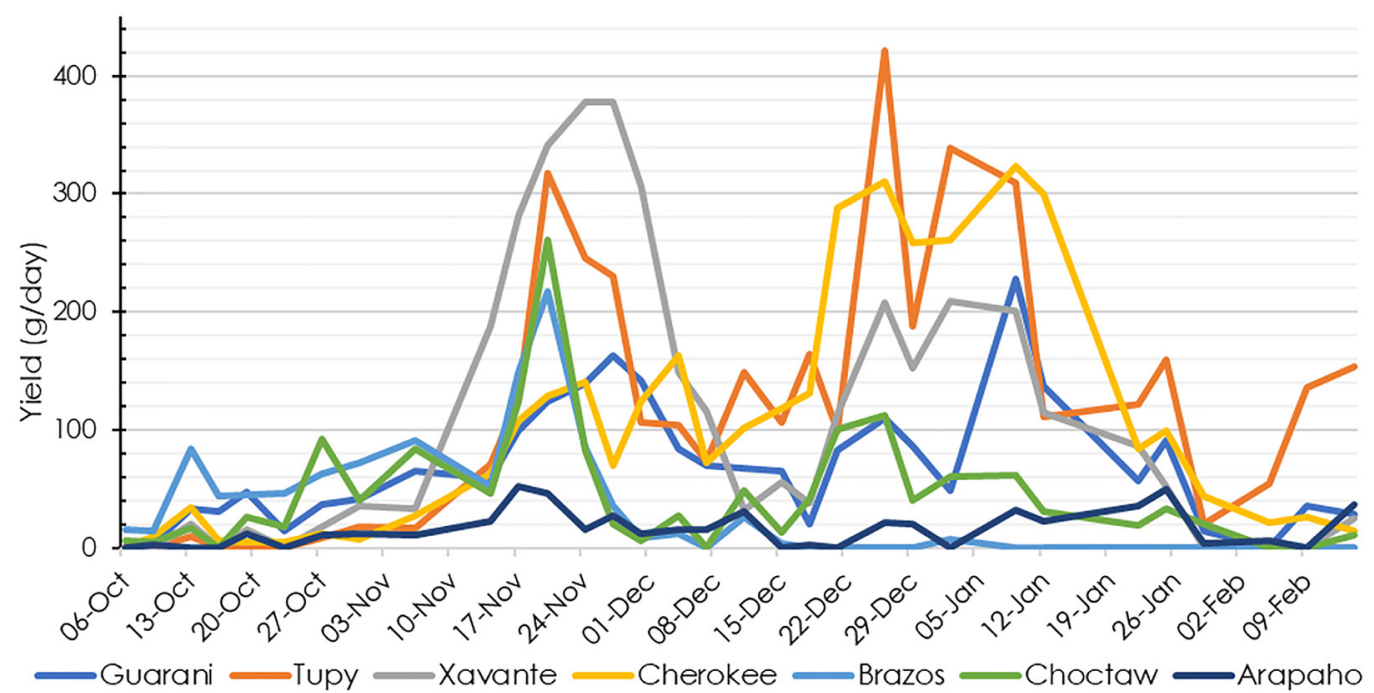

Figure 4. Harvest distribution (g/day) of blackberry cultivars during 2017-2018 cycle.

The importance of knowing the harvest distribution during the crop cycle is the observation of behaviors that allow production scheduling (Raseira \& Franzon, 2012). Thus, the producer can offer the product for a longer time, facilitating the sale and obtaining higher prices.

In the second cycle evaluated (2018/2019), cultivars presented phenological behavior quite distinct from each other (Figure 3). The first shoots were observed a little later than in the previous cycle, starting in mid-August for the first cultivars, in this case, 'Choctaw', 'Xavante' and 'Brazos'. The delay in budding may have been the effect of water stress at the end of the dormancy period in July / 2018.
The cultivars Tupy and Cherokee began to sprout very late in this cycle, with green tips only in late September. Their harvest started too late, showing the first ripe fruits in late November. Both were also the last to stop producing, ending their harvest in late January. Both cultivars have medium chilling hours requirement (from 200 to 300 h) (Raseira \& Franzon, 2012).

The harvest of the 2018/2019 cycle lasted from 63 to 78 days, presenting a decrease of 36 days compared with the previous cycle. Meanwhile, the availability of chilling hours increased by 37 hours in the second cycle related to the first one. Therefore, under the conditions of this study, the greater availability of cold generated a 
shorter cycle. On the other hand, Antunes et al. (2010), observed through the behavior of blackberry cultivars, in the region of Pelotas - RS, a longer duration of the crop cycle in the year that offers a larger amount of accumulated chilling hours.

Hussain et al. (2016) also reported short harvest periods, lasting around 50 days, in subtropical area for Tupy and Xavante cultivars.

Production peaks in the second cycle evaluated (Figure 5) were also irregular compared to the previous year, presenting different peak production dates for each cultivar. The period in which production was most concentrated was from late November and December, when the cultivars Brazos and Guarani had yields of approximately 500 grams in one day of harvest. A more localized production, as observed in this year, tends to generate lower sales prices, in addition to a short product offering period, hindering production flow. Considering a short post-harvest life, varying from 4 to 8 days depending on the cultivar (Cavender et al., 2019), production scheduling can greatly help to ensure good fruit prices.

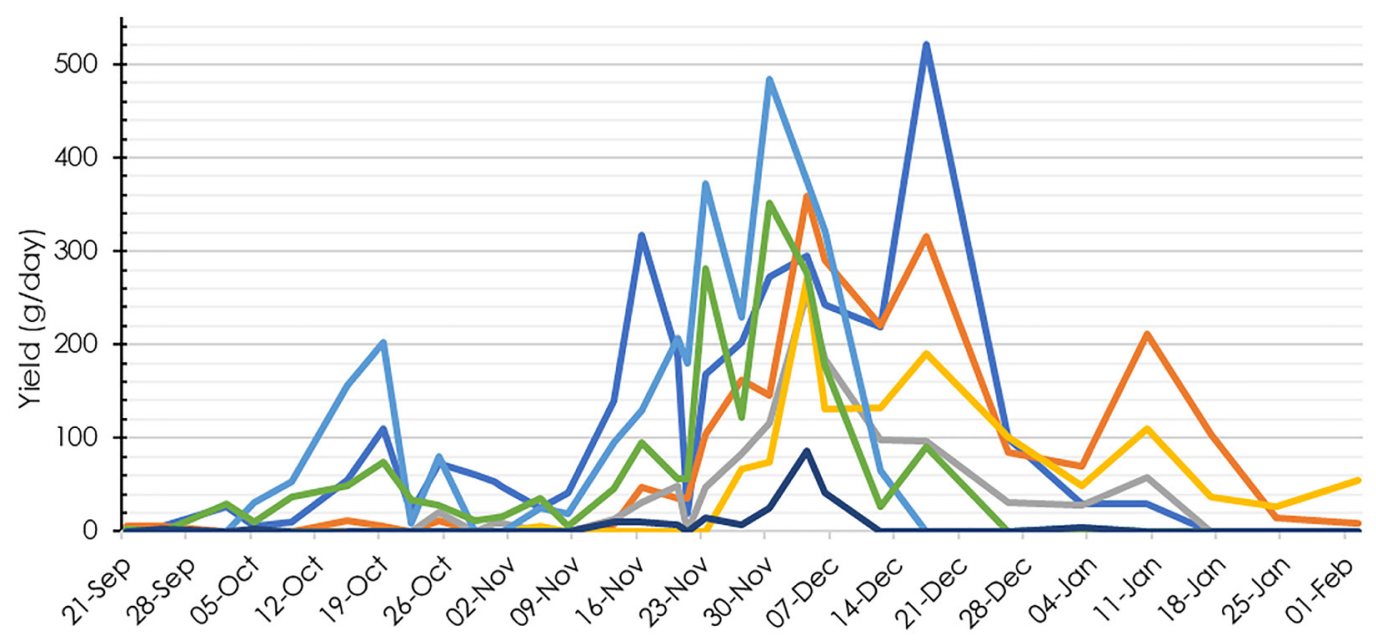

-Guarani -Tupy Xavante Cherokee Brazos Choctaw -Arapaho

Figure 5. Harvest distribution (g/day) of blackberry cultivars during 2018-2098 cycle.

The cultivars' yield was calculated by the average of the two years of evaluation. Results presented large variability among cultivars. The most productive cultivar produced eight times more than the least productive. This fact highlights the influence of genotype on the productive expression of this fruit and the necessity to find the most suitable cultivars for each growing region.

The highest yields were observed in the cultivars
Guarani, Tupy, Xavante, Cherokee, and Brazos. The highest one was observed in cultivar Tupy, producing $2,265.4 \mathrm{~kg} / \mathrm{ha}$ (Table 2). This productivity was similar to what observed Attilio et al. (2009), in the second year of cultivation of this same cultivar in the region of Selviria MS (Brazil), considered an area of tropical climate, whose average was $3,000 \mathrm{~kg} / \mathrm{ha}$.

Table 2. Average of production performance of blackberry cultivars in 2017/2018 and 2018/2019 cycles. Pinhais - PR.

\begin{tabular}{|c|c|c|c|}
\hline Cultivar & Production (g/plant) ${ }^{1}$ & Yield $(\mathrm{kg} / \mathrm{ha})^{1}$ & Weight (g/fruto) \\
\hline Tupy & $339.8 a$ & $2,265.4 \mathrm{a}$ & $5.1 \mathrm{a}$ \\
\hline Guarani & $306.0 \mathrm{a}$ & $2,040.3 a$ & $2.2 \mathrm{~d}$ \\
\hline Xavante & $259.9 \mathrm{a}$ & $1,732.7 \mathrm{a}$ & $4.2 \mathrm{~b}$ \\
\hline Cherokee & $256.1 \mathrm{a}$ & $1,707.3 \mathrm{a}$ & $3.0 \mathrm{c}$ \\
\hline Brazos & $228.4 \mathrm{a}$ & $1,522.8 \mathrm{a}$ & $3.9 \mathrm{~b}$ \\
\hline Choctaw & $187.7 \mathrm{ab}$ & $1,251.5 \mathrm{ab}$ & $3.1 \mathrm{C}$ \\
\hline Arapaho & $40.8 \mathrm{~b}$ & $271.8 \mathrm{~b}$ & $2.9 \mathrm{~cd}$ \\
\hline \multicolumn{4}{|l|}{ Cycles } \\
\hline $2017 / 2018$ & $254.5 \mathrm{~ns}$ & $1,696.9 \mathrm{~ns}$ & $3,7 \mathrm{a}$ \\
\hline $2018 / 2019$ & 207.9 & $1,386.7$ & $3,2 \mathrm{~b}$ \\
\hline F test (Cycle) & ns & ns & $* *$ \\
\hline F test (Cultivar) & $* * *$ & $* * *$ & $* * *$ \\
\hline F test (Cycle*Cultivar) & ns & ns & ns \\
\hline $\mathrm{CV}(\%)$ & 21.7 & 21.7 & 11.9 \\
\hline
\end{tabular}


The yield performance of all cultivars was very low compared to the average yield of blackberry, which, according to Antunes \& Raseira (2004) is about 10,000.00 $\mathrm{kg} / \mathrm{ha}$. There are also studies, such as Croge et al. (2019), which demonstrated yield values of up to $26,800.00 \mathrm{~kg} / \mathrm{ha}$ for the cultivar Tupy, in the Lapa - PR (Brazil) region, in a conventional and irrigated cultivation system.

However, under agroecological cultivation conditions, and therefore, with no use of agrochemicals, Antunes et al. (2010) found, in the region of Pelotas - RS (Brazil), yields ranging from 2,794 to $5,169 \mathrm{~kg} / \mathrm{ha}$ for cultivars Brazos and Tupy, respectively. In the years evaluated, no water stress was observed. Botelho et al. (2009) also found yields lower than the average, evaluating the performance of cultivar Xavante in organic farming in Guarapuava - PR (Brazil) region, with productivity of 3,026 $\mathrm{kg} / \mathrm{ha}$.

The observed yield of Cherokee cultivar was $1,707.3 \mathrm{~kg} / \mathrm{ha}$. Curi et al. (2015) found a similar yield for Cherokee cultivar in Lavras - MG (Brazil) region, which produced 2,240.9 $\mathrm{kg} / \mathrm{ha}$ in one of the evaluated cycles. The region also presented water stress during winter, being observed an accumulated rainfall from July to September smaller than $10 \mathrm{~mm}$ in the years evaluated (Curi et al., 2015).

The lowest yield was found for Arapaho cultivar, which produced an average of only $271.8 \mathrm{~kg} / \mathrm{ha}$, presenting an unfeasible production for the region. This small production can be explained by the high demand in the hibernal cold the cultivar presents. Moore \& Clark (1993) estimate that the cultivar's requirement for chilling hours is around 400 to $500 \mathrm{~h}$, an unmet number in the years evaluated. The cultivar was also one of the less productive found by Curi et al. (2015) in the region of Lavras - MG (Brazil), with an estimated yield of $2,162.1 \mathrm{~kg} / \mathrm{ha}$ in the year evaluated and by Villa et al. (2014) at Marechal Cândido Rondon - PR (Brazil), with the productivity of $651.99 \mathrm{~kg} / \mathrm{ha}$. The Xavante cultivar is thornless, which facilitates management, but usually, this characteristic decrease productivity and quality of the fruits produced (Antunes et al., 2014).

It should be noted that, even with low productivity, Attilio et al. (2009) demonstrated that average yields of $3,000.00 \mathrm{~kg} / \mathrm{ha}$ can already make fruit cultivation viable if its selling price is higher than $\$ 0,91$ / kilogram (updated price considering the IPCA). Considering the city of Pinhais - PR (Brazil), where this study was conducted, as a region of the green belt, very close and responsible for supplying the city of Curitiba, and an average purchase price of at least \$ 1.97 a kilogram in CEASA (Supply Central of Paraná
State) in harvest season, cultivation can become viable in the region, even with yields below that the expected average.

The largest fruit size was found for cultivar Tupy, with an average of $5.1 \mathrm{~g}$ per fruit. Villa et al. (2014) found a similar result, obtaining an average of $5.8 \mathrm{~g}$ per fruit of blackberries from cultivar Tupy in Marechal Cândido Rondon - PR (Brazil).

Xavante and Brazos cultivars produced fruits with an average of 4.2 and $3.9 \mathrm{~g}$, respectively. In cultivar Brazos, however, it was noted that the first fruits to ripen, tended to be on the edge of the bunch and the weights could reach $8.2 \mathrm{~g}$, while those that ripened later were much smaller, reaching $2.6 \mathrm{~g}$. Uneven fruit size harms marketing as fresh fruit, as smaller fruits become undesirable. As noted by Croge et al. (2019), fruits of the cultivar 'Tupy', which presented higher fresh mass, also presented higher consumer acceptability by appearance, when compared to other cultivars.

Smallest fruits were found in cultivar Guarani, with an average of $2.2 \mathrm{~g}$ per fruit. According to Antunes et al. (2010), the fruits of cultivar Guarani do tend to be smaller. They found values of $2.83 \mathrm{~g}$ per fruit for this cultivar. Smaller fruits have lower acceptability for fresh consumption and have a lower market value, generating lower remuneration. Even with smaller fruits, the cultivar presented the second highest yield of this work, with an average of 2,040.3 kilograms per hectare, therefore, the cultivar may be an interesting option for industrialization.

There was a significant difference in the size of the fruit produced comparing the two cycles evaluated. The first cycle produced larger fruits $(3.7 \mathrm{~g})$ than the second cycle (3.2 g). This may be associated with lower availability of water during September, October, and November/2018, which may have decreased fruit growth in the second cycle. Low yields observed in this research may be related to crop management problems. Considering that the region of implantation does not allow the use of chemicals to control phytosanitary problems, there was no control of pests that were present at the site.

During the evaluation of the experiment, it was possible to observe a high incidence of blackberry borer (Eulechriops rubi), one of the main problems observed by fruit producers also in other regions of Brazil (Muller et al., 2008).

Damage caused by the borer can be observed due to obstruction of the main branches of the plant caused by galleries opened by the larva. Galleries block the flow of sap, leading to loss of vigor and subsequent death of the branch (Muller et al., 2008). 
The borer control is extremely difficult, even in conditions where it is possible to use chemical insecticides, there is no product registered for this pest. It is recommended to prune, remove and burn contaminated material (Muller et al., 2008), however, the damage is only noticeable when the branch production is already compromised. During the experiment, many stems had to be removed due to the presence of borer, with a decrease in the bud load and production.

Other problems were observed during the evaluation, as the occurrence of rust on old leaves, which attempt to reduce the inoculum was carried out with the application of sulfocalcic syrup; the presence of leaf-cutting ant, which infestation was controlled with the use of local bait; and the rotting of fruits in the field. However, further studies should be carried out to identify the incidence of the pests in these conditions and to point out the appropriate integrated management.

The use of irrigation should also be considered in the area, since historically there has been a decrease in precipitation during the winter period, which can cause water stress on the plant, delaying the beginning of the crop cycle and, sometimes, decreasing the rate of budding.

The larger longitudinal diameters were found in Tupy and Xavante cultivars (Table 3). Croge et al. (2016) also found larger longitudinal diameters for these two cultivars in Cerro AzUl - PR (Brazil), however, the diameter found by the authors reached $28.3 \mathrm{~mm}$ for the cultivar Tupy, while, in this work, the highest average found was $20.7 \mathrm{~mm}$.

Table 3. Average of equatorial and longitudinal diameter (mm) of blackberries in 2017/2018 and 2018/2019 cycles. Pinhais - PR.

\begin{tabular}{cccc}
\hline Cultivar & Longitudinal diameter $(\mathrm{mm})$ & Equatorial diameter $(\mathrm{mm})$ & Ratio between diameters \\
\hline Tupy & $20.7 \mathrm{a}$ & $23.9^{\mathrm{ns}}$ & $1.15^{\mathrm{ns}}$ \\
Xavante & $20.3 \mathrm{a}$ & 24.0 & 1.18 \\
Cherokee & $17.7 \mathrm{ab}$ & 19.4 & 1.09 \\
Brazos & $17.9 \mathrm{ab}$ & 20.3 & 1.13 \\
Choctaw & $16.7 \mathrm{~b}$ & 19.7 & 1.16 \\
Arapaho & $16.9 \mathrm{~b}$ & 19.2 & 1.13 \\
Guarani & $15.2 \mathrm{~b}$ & 18.2 & 1.19 \\
\hline Cycles & & & $1.2 \mathrm{~ns}$ \\
$2017 / 2018$ & $22.2 \mathrm{a}$ & $18.8 \mathrm{a}$ & 1.1 \\
$2018 / 2019$ & $19.2 \mathrm{~b}$ & $17.0 \mathrm{~b}$ & $\mathrm{~ns}$ \\
\hline $\mathrm{F}$ test (Cycle) & $*$ & $* * *$ & $\mathrm{~ns}$ \\
$\mathrm{~F}$ test (Cultivar) & $*$ & $* * *$ & $\mathrm{~ns}$ \\
$\mathrm{~F}$ test (Cycle*Cultivar) & $\mathrm{ns}$ & 12.068 .8 & 7.3610 .4 \\
\hline CV $(\%)$ & 15.3 & &
\end{tabular}

The smallest longitudinal diameter was found for the Guarani cultivar, with $15.2 \mathrm{~mm}$. Croge et al. (2019) also found lower values for this cultivar in Lapa - PR (Brazil). This behavior was already expected since the genetic characteristics of the Guarani cultivar classify it as a producer of smaller fruits (Antunes \& Hoffmann, 2012). The cultivars Choctaw and Arapaho also showed fruits with smaller longitudinal diameters.

Regarding equatorial diameter, the cultivars did not show significant differences between them and values ranged from 15.3 to $25.2 \mathrm{~mm}$. The diameter ratio allows checking which fruits are more rounded. This characteristic also did not show any significant difference between cultivars.

Longitudinal and equatorial diameters showed significant differences between the cycles. The first cycle produced larger longitudinally and equatorially fruits than the second cycle. This is due to the lack of water during the fruit growth period in the second evaluated cycle.

The values of soluble solids varied from 7.3 to $9.4^{\circ}$ Brix (Table 4). An amount that allows the commercialization destined to consumption in natura of the fruit. Villa et al. (2014) found a Brix for the Tupy cultivar of $8.0^{\circ}$ in the region of Marechal Cândido Rondon - PR (Brazil). Hirsch et al. (2012) found higher values in the region of Pelotas RS, with soluble solids averages of $10.1^{\circ}$ Brix for the cultivar Tupy and $10.2^{\circ}$ Brix for Guarani.

The highest concentration of soluble solids was found in the cultivar Xavante, which had an average of $9.4^{\circ}$ Brix. However, the fruits of this cultivar were one with the highest acidity, presenting 1.25 and $1.63 \%$ of citric acid. Fruits of 'Xavante' are reported as more acidic and with less acceptability for fresh consumption, relating to the overall impression, appearance, firmness and flavor attributes (Antunes \& Raseira, 2004; Croge et al., 2019).

The cultivar that presents the lowest concentration 
Table 4. Chemical properties of blackberry fruits in $2017 / 2018$ and $2018 / 2019$ cycles. Pinhais-PR.

\begin{tabular}{|c|c|c|c|c|c|}
\hline \multirow[t]{2}{*}{ Cultivar } & \multirow[t]{2}{*}{ Soluble Solids ( ${ }^{\circ}$ Brix) } & \multirow[t]{2}{*}{$\mathrm{pH}$} & \multicolumn{2}{|c|}{ Titratable acidity (\% citric acid) } & \multirow[t]{2}{*}{ Ratio (SS/AT) } \\
\hline & & & $2017 / 2018$ & $2018 / 2019$ & \\
\hline Guarani & $8.2 \mathrm{ab}$ & $3.3 \mathrm{~ns}$ & $1.28 \mathrm{Aa}$ & $1.35 \mathrm{Ab}$ & $6.3 \mathrm{~ns}$ \\
\hline Tupy & $7.8 \mathrm{ab}$ & 3.1 & $1.02 \mathrm{Ba}$ & $1.31 \mathrm{Ab}$ & 6.8 \\
\hline Xavante & $9.4 \mathrm{a}$ & 3.1 & $1.25 \mathrm{Ba}$ & $1.63 \mathrm{Aab}$ & 6.7 \\
\hline Cherokee & $9.1 \mathrm{ab}$ & 3.0 & $1.23 \mathrm{Aa}$ & $1.49 \mathrm{Aab}$ & 6.8 \\
\hline Brazos & $7.3 \mathrm{~b}$ & 3.1 & $1.11 \mathrm{Ba}$ & $1.83 \mathrm{Aa}$ & 5.4 \\
\hline Choctaw & $8.4 \mathrm{ab}$ & 3.2 & $1.24 \mathrm{Ba}$ & $1.56 \mathrm{Aab}$ & 6.3 \\
\hline Arapaho & $9.1 \mathrm{ab}$ & 3.1 & $1.36 \mathrm{Aa}$ & $1.54 \mathrm{Aab}$ & 6.4 \\
\hline \multicolumn{6}{|l|}{ Cycles } \\
\hline $2017 / 2018$ & $8.9 \mathrm{a}$ & $3.3 \mathrm{a}$ & & & $7.5 \mathrm{a}$ \\
\hline $2018 / 2019$ & $7.9 \mathrm{~b}$ & $2.9 \mathrm{~b}$ & & & $5.3 \mathrm{~b}$ \\
\hline F test (Cycle) & $* * *$ & $* * *$ & \multicolumn{2}{|c|}{$* * *$} & $* * *$ \\
\hline F test (Cultivar) & $* *$ & ns & \multicolumn{2}{|c|}{$*$} & ns \\
\hline F test (Cycle*Cultivar) & ns & ns & \multicolumn{2}{|c|}{ * } & ns \\
\hline $\mathrm{CV}(\%)$ & 9.7 & 5.8 & \multicolumn{2}{|c|}{11.6} & 16.8 \\
\hline
\end{tabular}

of soluble solids was Brazos, with an average of $7.3^{\circ}$ Brix. This value was below the average usually found for this cultivar, which varied from $7.5^{\circ}$ Brix found by Campagnolo \& Pio (2012) in Marechal Cândido Rondon - PR (Brazil), to $9.3^{\circ}$ Brix in a subtropical region, found by Tadeu et al. (2015). This cultivar showed a ratio between soluble solids and titratable acidity of $5.4 \%$, the lowest value found among all cultivars of this work.

According to Villa et al. (2014), changes in the values of soluble solids occur mainly due to variations in climatic conditions occurring between regions and years. The contents of chemical compounds vary, mainly, due to the incidence of solar radiation and thermal amplitude. A higher concentration of soluble solids is generally found in places that provide higher temperatures and a bigger availability of light during the fruit production phase (Ali et al., 2011; Tullio \& Ayub, 2013).

Thermal amplitude influences the photosynthetic and respiratory system's balance, and, consequently, the accumulation of energy, being related to the biosynthesis of phenolic compounds (Pandolfo el al., 2007). The monthly average of thermal amplitude varied from $8.25^{\circ} \mathrm{C}$ and $12.94{ }^{\circ} \mathrm{C}$ during the cycles evaluated. The highest values, around $19^{\circ} \mathrm{C}$, were found in August and September. Highest monthly averages were found in October and December, so in the harvest period, which can contribute to the accumulation of soluble solids.

Tadeu et al. (2015) observed, in the region of Lavras - MG (Brazil), a variation of soluble solids from 9.05 to 11.52 for 'Guarani', 'Tupy', 'Brazos', 'Cherokee', 'Choctaw', 'Comanche' and 'Caingangue'. The values of maximum average temperatures found in that region during the production period were higher than $27^{\circ} \mathrm{C}$, sometimes reaching $30^{\circ} \mathrm{C}$, an average temperature of $5^{\circ} \mathrm{C}$ above than the observed in the Pinhais - PR (Brazil) region.

The $\mathrm{pH}$ values did not differ statistically between cultivars and ranged from 3.0 to 3.3. Hirsch et al. (2012) found in blackberry, cultivated in the south of the country, values of $\mathrm{pH}$ from 2.78 to 3.08. According to Hirsch et al. (2012), these values are expected for this species, due to the naturally acidic sweet-acid flavor, and these values are desirable for fruit industrialization, dispensing the use of acidulants, as this $\mathrm{pH}$ is already great for the gel formation. Besides, low pH values tend to be sought by the industry, as they increase the resistance of food to microbiological infections (Hirsch et al., 2012).

Titratable acidity values presented significant interaction between cycle and cultivars. The values found in the first cycle were lower than the second. Values ranged from 1.02 to $1.83 \%$, agreeing with the pattern values found by Hirsch et al. (2012), which varied from 1.3 to $1.6 \%$ of citric acid. These values are desirable for the manufacture of juices and pulps. The lowest acidity cultivar was the "Tupy", with $1.02 \%$ of citric acid in the first cycle and $1.31 \%$ in the second. Brugnara (2016) also found the lowest acidity value for the cultivar Tupy, presenting $1.27 \%$ of citric acid, supporting the high acceptability of the cultivar in the market for fresh consumption.

Obtaining the ratio of soluble solids and titratable acidity is important to determine the sweet-acid balance of the fruit, demonstrating which is their best destination. In this work, the values ranged from 5.4 to 6.8 , with no significant difference between cultivars. Brugnara (2016) reported a similar ratio average, ranging from 5.84 for the Xavante cultivar to 7.09 for Tupy cultivar. These values are superior to those found by Croge et al. (2019) for the cultivars Tupy, Guarani, Xavante and Cherokee, which 
was between 3.9 and 6.4. In that same study, Croge et al. (2019) evaluated the acceptance of the fruits and noted that the fruits of the cultivars Tupy and Cherokee, whose SS/AT ratio was 6.3 and 6.4 , had an acceptability index by taste of 79.6 and $72.7 \%$, respectively, higher values among the studied cultivars.

\section{Conclusions}

Under the conditions of the present study, in Environmental Protection Area of Pinhais - PR, the Tupy, Guarani, Xavante, Cherokee and Brazos cultivars demonstrated the best productivities. However, yield was below the average of these cultivars in other regions. The harvest period extended from November to January.

Brazos has the earliest harvest, Guarani and Xavante cultivars are intermediate and Tupy and Cherokee present later harvests.

Cultivar Tupy showed the best attributes in average fruit quality, being indicated for marketing as fresh fruit. The other cultivars should be indicated for processing.

\section{Acknowledgments}

This study was financed in part by Coordenação de Aperfeiçoamento de Pessoal de Nível Superior Brazil (CAPES) - Finance Code 001 and Brazilian National Council for Scientific and Technological Development (CNPq) Process 477.289/2013-4.

\section{References}

Ali, L., Svensson, B., Alsanius, B.W., Olsson, M.E. 2011 . Late season harvest and storage of Rubus berries - Major antioxidant and sugar levels. Scientia Horticulturae 129(3): 376-381.

Antunes, L.E.C., Goncalves, E.D., Trevisan, R. 2010. Phenology and production of blackberry cultivars in agroecological system. Ciência Rural 40(9): 1929-1934.

Antunes, L.E.C., Pereira, I.D.S., Picolotto, L., Vignolo, G.K., Gonçalves, M.A. 2014. Produção de amoreira-preta no Brasil. Revista Brasileira de Fruticultura 36(1): 100-111.

Antunes, L.E.C., Hoffmann, A. 2012. Pequenas frutas - O produtor pergunta, a Embrapa responde. Embrapa, Brasília, Brazil. 194 p.

Antunes, L.E.C., Raseira, M.C.B. 2004. Aspectos técnicos da cultura da amora-preta. Embrapa Clima Temperado, Pelotas, Brazil. 51 p.

Attilio, L.B., Boliani, A.C., Tarsitano, M.A.A. 2009. Custo de produção de amora-preta em região tropical. Revista Brasileira de Fruticultura 31 (4): 1042-1047.

Botelho, R.V., Pavanello, A.P., Broetto, D., Scisloski, S.F., Baldissera, T.C. 2009. Fenologia e produção da amoreira-preta sem espinhos cv. Xavante na região de
Guarapuava-PR. Scientia Agraria 10(3): 209-214.

BRASIL. Instrução normativa $n^{\circ} 46$, de 06 de outubro de 2011. Lei $n^{\circ}$ 10831, de 23 de dezembro de 2003. Diário Oficial da República Federativa do Brasil, Poder Executivo, Brasília, DF, 06 October, 2011.

Brugnara, E.C. 2016. Produção, época de colheita e qualidade de cinco variedades de amoreira-preta em Chapecó, SC. Agropecuária Catarinense 29(3): 71-75.

Campagnolo, M.A., Pio, R. 2012. Phenological and yield performance of black and redberry cultivars in western Paraná State. Agronomy 34(4): 439-444.

Cavender, G., Liu, M., Fernandez-Salvador, J., Hobbs, D., Strik, B., Frei, B., Zhao, Y. 2019. Effect of different commercial fertilizers, harvest date, and storage time on two organically grown blackberry cultivars: physicochemical properties, antioxidant properties, and sugar profiles. Journal of Food Quality 2019: e-17.

Croge, C.P., Cuquel, F.L., Biasi, L.A., Bona, C.D. 2016. Performance of blackberry cultivars in Cerro Azul - PR. Revista Brasileira de Fruticultura 38(3): e-141.

Croge, C.P., Cuquel, F.L., Biasi, L.A., Bona, C.D., Pintro, P.T.M. 2019. Agronomic performance of Blackberry cultivars in Lapa-PR. Revista Brasileira de Fruticultura 41 (2): e-101.

Curi, P.N., Pio, R., Moura, P.H.A., Tadeu, M.H., Nogueira, P.V., Pasqual, M. 2015. Produção de amora-preta e amora-vermelha em Lavras-MG. Ciência Rural 45(8): 1368-1374.

Fachinello, J.C., Pasa, M.D.S., Schmtiz, J.D., Betemps, D.L. 2011. Situação e perspectivas da fruticultura de clima temperado no Brasil. Revista Brasileira de Fruticultura 33(1): 109-120.

Hirsch, G.E., Facco, E.M.P., Rodrigues, D.B., Vizzotto, M., Emanuelli, T. 2012. Caracterização físico-química de variedades de amora-preta da região sul do Brasil. Ciência Rural 42(5): 942-947.

Hussain, I., Roberto, S.R., Fonseca, I.C.B., de Assis, A.M., Koyama, R., Antunes, L.E.C. 2016. Phenology of 'Tupy' and 'Xavante' blackberries grown in a subtropical area. Scientia Horticulturae 201: 78-83.

Instituto Adolfo Lutz. 2005. Métodos físico-químicos para análise dos alimentos. Ministério da Saúde, Brasília, Brasil. $1115 \mathrm{p}$.

Martins, W.A., Santos, S.C., Jara, R.S., de Souza, J.L.A.C., Galvão, J.R., Biscaro, G.A. 2019. Fenologia e demanda térmica de amoreira-preta cv. Tupy. Revista de Ciências Agrárias 42(3): 720-730.

Moore, J.N., Clark, J.R. 1993. 'Arapaho' erect, thornless blackberry. HortScience 28(8): 861-862.

Muller, C., Botton, M., Pagot, E., Schneider, E. 2008. Ocorrência e danos de Eulechriops rubi (Coleoptera: Curculionidae) na cultura da amora-preta. Agropecuária Catarinense 21 (2): 55-57. 
Pandolfo, C., Massignan, A.M., de Lima, M.F., da Silva, A.L. 2018. Sistemas atmosféricos que afetam as variáveis meteorológicas e o teor de sólidos solúveis ( ${ }^{\circ}$ Brix) de frutos da videira Cabernet Sauvignon (Vitis vinifera L.) no período da maturação em Santa Catarina. Agrometeoros 26(1): 103-111.

Pauletti, V., Motta, A.C.V. 2017. Manual de adubação e calagem para o estado do Paraná. Sociedade Brasileira de Ciência do Solo, Curitiba, Brazil. 482 p.

Raseira, M., Franzon, R.C. 2012. Melhoramento genético e cultivares de amora-preta e mirtilo. Informe Agropecuário 33: 11-20.

Reyes-Carmona, J., Yousef, G.G., Martínez-Peniche, R.A., Lila, M.A. 2005. Antioxidant capacity of fruit extracts of blackberry (Rubus sp.) produced in different climatic regions. Journal of Food Science 70(7): 497-503.

Safley, C.D., Boldea, O., Fernandez, G.E. 2006. Estimated costs of producing, harvesting, and marketing blackberries in the southeastern United States. HortTechnology 16(1): 109-117.

Schmidt, K., Höhn, H., Graf, B., Höpli, H. 2001. Phänologische entwicklungsstadien der Himbeere (Rubus idaeus L.). Forschung 8: 215-222.

Segantini, D.M., Leonel, S., Cunha, A.R.D., Ferraz, R.A., Ripardo, A.K.D.S. 2014. Exigência térmica e produtividade da amoreira-preta em função das épocas de poda. Revista Brasileira de Fruticultura 36(3): 568-575.

SIMEPAR. Sistema Meteorológico do Paraná. Dados climáticos da Estação Meteorológica de Pinhais-PR. 2019. faleconosco@simepar.br. <Access on 14 Aug. 2019>

Tadeu, M.H., de Souza, F.B.M., Pio, R., do Valle, M.H.R., Locatelli, G., Guimarães, G.F., Silva, B.E.C. 2015. Poda drástica de verão e produção de cultivares de amoreira-preta em região subtropical. Pesquisa Agropecuária Brasileira 50(2): 132-140.

Tullio, L., Ayub, R.A. 2013. Produção da amora-preta cv. Tupy, em função da intensidade da poda. Semina. Ciências Agrárias 34(3): $1147-1152$.

Vieites, R.G. 2010. Agricultura sustentável: uma alternativa ao modelo convencional. Revista Geografar 5(2): 01-12.

Villa, F., Silva, D.F., Barp, F.K., Stumm, D.R. 2014. Amoraspretas produzidas em região subtropical, em função de podas, sistemas de condução e número de hastes. Agrarian 7(26): 521-529.

Conflict of Interest Statement: The authors declare that the research was conducted in the absence of any commercial or financial relationships that could be construed as a potential conflict of interest.

All the contents of this journal, except where otherwise noted, is licensed under a Creative Commons Attribution License attribuition-type BY. 